\title{
Introduction: business, civil society and the 'new' politics of corporate tax justice: paying a fair share?
}

\section{Ainsley Elbra and Richard Eccleston}

Blatant corporate tax avoidance has attracted the ire of politicians, citizens and consumers the world over in recent years. Since the financial crisis of 2008, international taxation has become a mainstream political issue championed by social justice campaigners and the progressive press the world over. Globally, governments and intergovernmental organisations have announced a range of reforms designed to ensure that MNCs pay their 'fair share' of tax, while some of the world's most powerful and profitable firms have been subjected to multibillion-dollar fines.

But has anything changed? Perhaps.

In 2012 Google chairman Eric Schmidt was defiantly unapologetic that his firm had avoided an estimated \$2 billion tax liability, explaining that Google was 'naturally capitalistic' (Kavoussi 2012). Yet, by early 2016, after much ridicule and condemnation, Google agreed to pay £120 million sterling in back taxes in the UK. This modest act of contrition has subsequently been dwarfed by the European Commission's $€ 13$ billion state aid case against fellow tech giant Apple handed down in September 2016. The legal ambiguity, politicisation and vast sums involved in these international tax cases clearly warrant closer examination.

Indeed, the Google and Apple cases highlight many of the questions central to this study. Has Google's tax strategy been influenced by regulatory reforms or is the company responding to activist campaigns and the threat of reputational damage? Is the tax to be paid a 'fair' amount or a token gesture? Will other lower-profile companies feel obliged to follow Google's lead? Will large-scale international tax litigation against MNC firms be upheld? Will increasing legal and financial risks influence corporate tax behaviour? Can tax justice campaigns orchestrated by NGOs have a significant and sustainable impact on tax compliance? More generally, what do these developments say about the potential for new forms of tax governance in the twenty-first century? Are they an alternative to formal 
regulation or are such developments complementary? This volume sets out to examine these questions, and in doing so represents the first systematic study into the effectiveness and impact of emerging forms of tax activism and its impact on corporate governance and taxation.

This study is undertaken in the context of the post-crisis global economy, where governments continue to face budgetary challenges arising from high and often unsustainable levels of public debt exacerbated by weak economic and revenue growth. Many governments have been forced to respond to the challenge of fiscal consolidation and budget repair by implementing so-called 'austerity' measures aimed at reducing government expenditure, particularly in the area of social spending. One response to these mounting budget challenges is that governments and intergovernmental organisations, such as the EU and the OECD, are also seeking ways by which they can increase tax revenues without compromising economic growth or creating a domestic political backlash. The growing need to increase tax revenue in relatively pain-free ways has created strong incentives for national governments to develop new strategies to limit multinational tax avoidance.

Yet the campaign against MNC tax avoidance has not been led from within government. Indeed, the last decade has seen a new politics of global tax justice emerge as the hitherto technical domain of international tax has received unprecedented public attention (this volume, Chapter 3). This agenda has been championed by 'tax justice' activists and the media and has resonated with voters, many of whom are negatively affected by the aforementioned austerity measures and see multinational tax avoidance as a root cause of economic inequality and as a failure of democratic governance. Growing political demands to address corporate tax avoidance have triggered a conventional regulatory response through intergovernmental organisations such as the OECD. The most recent of these efforts, the OECD's base erosion and profit shifting (BEPS) initiative, represents significant progress in reform to the global tax regime (this volume, Chapter 2). However, the initiative faces several challenges, not least of which is the need to maintain international cooperation in the context of the divergent interests of participating states. Tax justice NGOs have welcomed these initiatives and their promise of greater tax transparency but argue that more ambitious and far-reaching reforms will be necessary to counter aggressive international tax planning and avoidance (Eccleston and Smith 2016; Picciotto 2016). As will be argued in subsequent chapters, many analysts argue that addressing MNC tax avoidance demands fundamental change to the century-old legal basis of the international tax regime and deeply held norms regarding fiscal sovereignty and competition (Rixen 2008; Dietsch 2015; van Apeldoorn 2016). It is this ambitious paradigm shift which tax justice NGOs are seeking. 
This Introduction sketches the emergence of tax justice NGOs, the advocacy strategies they are employing and the reforms and innovative governance regimes they are promoting. In particular, it outlines the significant political challenges associated with corporate tax reform and the incremental policy change which has been achieved to date. It concludes by presenting the theoretical and empirical aims of this volume and an overview of the study.

\section{THE CHALLENGE OF MULTINATIONAL TAX AVOIDANCE}

The financial crisis that first disrupted global markets in 2008 has had significant political and fiscal consequences. Across the OECD the crisis and its aftermath have had a profound impact on public finances, with public debt across the OECD increasing from an average of 73 per cent of GDP in 2007 to 111 per cent in 2014 (OECD 2014a). Tepid economic growth has made the task of budget repair more difficult, with many governments implementing controversial 'austerity' measures in an attempt to rein in deficits and reassure creditors. While most governments have been reluctant to increase domestic taxes for fear of compromising economic recovery or triggering a political backlash, there has been a much greater willingness to implement anti-avoidance and anti-evasion measures designed to ensure that wealthy individuals and MNCs pay more tax. In addition to bolstering revenue, proposals to crack down on aggressive international tax planning resonate with growing political demands to improve equity and fairness in the global economy.

This political context has created an environment in which emerging tax justice NGOs have been able to cultivate the media and successfully draw the wider public's attention to the issue of corporate tax avoidance through direct 'name and shame' campaigns and associated exposés (Christians 2013; Seabrooke and Wigan 2015). In addition, a series of high-profile tax avoidance scandals have contributed to growing calls for business to pay its 'fair share'. Together, these factors have led to corporate tax avoidance emerging as a key issue for policymakers and voters, many of whom see more effective multinational taxation as a solution to budgetary challenges (this volume, Chapter 3).

This study provides a detailed analysis of this 'new' political economy of international taxation in which tax justice NGOs and the media are influencing the international tax agenda, policy responses and corporate strategy. The volume not only assesses the prospects for global tax justice and the extent to which fiscally challenged governments are going to be 
able to extract revenues from large corporations, but also provides a critical assessment of the changing nature of power and authority in the global economy and the prospects of new modes of economic governance.

The political salience of the campaign against corporate tax avoidance is unsurprising given the growing awareness of the immense scale of the problem. As will be explained in greater detail below, the revenue forgone, or the 'tax gap' associated with legal tax planning, is notoriously difficult to estimate. The US Congressional Research Service notes that, while estimates vary greatly, it is likely that the revenue losses from tax evasion by US-based firms alone are approximately $\$ 100$ billion per year (Gravelle 2015). UNCTAD (2015, p. 201) reports that multinational tax avoidance undertaken through profit shifting costs developing countries between $\$ 70$ billion and $\$ 120$ billion per annum. The OECD has estimated that revenue losses from base erosion and profit shifting alone are US\$100 billion to US\$240 billion per annum (OECD 2015).

The growing awareness of the magnitude of multinational tax avoidance has led to increased attention and scrutiny on MNCs suspected of engaging in these practices. Over the last decade this increased scrutiny has taken many forms, including media campaigns. Since the mid-2000s the UK's Guardian newspaper has been running a high-profile campaign against tax havens and multinational tax avoidance, including opinion pieces from individuals associated with tax justice NGOs, such as Tax Justice Network (TJN). In the US the New York Times has led the campaign, and in Australia the Fairfax press and the national broadcaster, the ABC, have also sought to highlight the issues of corporate tax avoidance (Aston and Wilkins 2014). Similarly, other more specific developments, such as the International Consortium of Investigative Journalists' success in obtaining and publishing the 'Luxembourg Leaks' and 'Panama Papers', have demonstrated the scale of international tax avoidance, ensuring the issue remains on the public agenda (Christians 2015).

Governments have responded to these calls by establishing various hearings and inquiries into the complex tax avoidance mechanisms used by MNCs. In 2013 the US Senate held an inquiry into 'Offshore Profit Shifting and the U.S. Tax Code'. In 2016, the UK Treasury Committee launched a hearing into 'UK Tax Policy and the Tax Base'. These efforts have been replicated in smaller jurisdictions, such as Australia, where a Senate inquiry into corporate tax avoidance was held in 2015 (Australian Senate 2015). The European Commission has also prioritised addressing tax evasion and avoidance in order to combat the negative impact of tax competition between member states, culminating in the $€ 13$ billion state aid ruling against Apple handed down in September 2016. Yet despite growing concern about corporate tax avoidance, the issue of whether tax 
competition ought to be regulated is deeply contested and represents a significant barrier in reaching multilateral consensus on reforming the international corporate tax regime.

These inquiries all sought to quantify the magnitude of tax avoidance and the cost to the respective national economies. In the process, representatives of multinational firms were asked to explain and justify the complex tax arrangements they employ. However, in many cases the firms engaged in the most egregious tax avoidance schemes made little attempt to deny or downplay the effects of these tax regimes. Instead, they argued that their arrangements complied with the rules of the international taxation system and simply took advantage of the existing regulations and associated loopholes that govern global taxation in order to enhance profits. Indeed, Apple CEO Tim Cook acknowledged that he 'hates the current tax system' and that Apple wants to make a 'constructive contribution to how it could be made simpler and more straightforward' (Weckler 2016). These are noble sentiments, but how might the global tax regime be made 'fairer'? If such reform is unattainable, do large corporations have ethical obligations to pay taxes beyond what is legally required? If so, what constitutes a 'fair' tax burden and how can this be determined in an objective and legitimate way? At a more pragmatic, political level, can NGOs and citizens use their resources to influence the international tax reform agenda and associated corporate behaviour?

\section{THE DEMOCRATIC GOVERNANCE OF CONTEMPORARY CAPITALISM}

The ability of business to develop complex corporate tax strategies to circumvent domestic tax regulation is but one example of modern corporations exploiting their scale and associated political power to further their commercial interests. Business is able to exploit inconsistencies and loopholes in the liberal yet state-based economic system of the early twenty-first century to avoid paying taxes in order to maximise profit. The power of MNCs in particular to avoid paying taxes has a number of dimensions. Marxist and radical liberal scholars such as Lindblom (1977) have long argued that modern capitalism privileged the norm of profitability, which in turn legitimised business power and the central role of private firms as the drivers of economic growth. In the liberalised, post-Bretton Woods international economic order, firms can make credible threats to withhold or transfer investment to jurisdictions with lower taxes and more favourable regulation. Indeed, revisionist scholars such as Bell (2012) have argued that norms regarding economic competition have become so 
entrenched that governments and policymakers promote capital-friendly policy irrespective of any overt threat of capital flight. As will be argued in subsequent chapters, the risk of destructive regulatory competition is particularly acute in the 'offshore world' of international taxation given that MNCs can easily transfer portfolio investment and profits to lowtax jurisdictions through the use of corporate structures and financing arrangements without relocating production.

One tangible consequence of the offshore world has been the proliferation of tax havens in the final quarter of the twentieth century. Palan (2002) rightly argues that the emergence of tax havens is the result of the combined forces of strengthened state sovereignty and financial liberalisation. He suggests that the rise of the offshore world can be attributed to a coinciding of states' enhanced ability to establish the 'legal facility for juridical relocation', and financial liberalisation (Palan 2002, p. 153). As a result, tax havens have been able to commercialise state sovereignty through the establishment of 'virtual' state systems that feed off the legal infrastructure of 'real' state systems (Palan 2002, p. 172). The increased presence of tax havens, both small and large, has therefore encouraged regime shopping or a race to the bottom as firms search for the most 'attractive' regulatory settings, while states seek to compete on the same basis.

It can be argued that the ability of firms to exploit these developments and create competition between states highlights the undemocratic nature of modern capitalism, because while states are formally sovereign they are increasingly unable to tax capital at a rate citizens desire (Dietsch 2015, chapter 1). As a result, the capacity of national governments to raise revenue is constrained, which in turn affects fiscal sustainability and spending on social services. Furthermore, individual taxpayers are then required to shoulder a greater share of the tax burden to make up for the loss of tax revenue from large firms. Lastly, businesses that do not or cannot develop complex tax arrangements and instead abide by the spirit of domestic tax laws are placed at a disadvantage when competing with those multinational firms that do take advantage of the weaknesses inherent in the global tax system. These factors highlight growing inequality in the global tax system, which unfairly affects individuals through increasing the tax burden on income and consumption while also disadvantaging small to medium firms that do not engage in tax avoidance (Clausing 2016; Henry 2016).

By examining the challenges of multinational tax avoidance, it can be shown that state-based governance is struggling to respond to the challenges of global capitalism. All but the most powerful states lack the power to act unilaterally in order to prevent tax minimisation, and efforts to challenge firms in domestic settings, such as through government 
inquiries, have yielded little to date in the way of reform. Yet, as outlined in the following chapters, the slow pace of multilateral reform does not offer immediate solutions to these challenges either. As a result, it appears that, despite efforts at the national and global levels, traditional forms of public governance alone are unlikely to address the challenge of tax avoidance. On a more optimistic note, there is evidence that non-state actors such as civil society groups and firms themselves have the potential to act as catalysts of reform of the global corporate tax system. Ultimately, we argue that hybrid regimes with elements of public and private authority offer the best prospects of influencing corporate behaviour in the international tax arena.

\section{THE POLITICAL ECONOMY CHALLENGES OF ADDRESSING MULTINATIONAL TAX AVOIDANCE}

The deregulation of the global financial system from the 1970s onwards provided firms with greater opportunities to shift capital, labour and operations to jurisdictions that offered more appealing investment conditions. The potential for firms to exploit this freedom has been the subject of much of the globalisation literature, and in the field of corporate taxation there is considerable evidence of firms exploiting liberalisation to minimise taxation obligations (Genschel and Schwarz 2011; Rixen 2011; Dietsch and Rixen 2016). This financial arbitrage goes to the very core of the challenge of global corporate taxation and has thus been the focus of both multilateral and unilateral reform efforts.

The OECD's first efforts at highlighting the issue of tax competition, evasion and avoidance resulted in its 1998 report Harmful Tax Competition: An Emerging Global Issue, which represented the first attempt by the intergovernmental organisation to define, identify and regulate tax havens. Despite these broader ambitions, subsequent reforms focused on improving tax transparency to stop tax havens being used for unlawful tax evasion, while the more contentious issues of international tax avoidance and competition were largely ignored (Eccleston 2013, chapter 2). By 2000, with the election of a Republican administration in the US, the international tax reform agenda had stalled, having become a victim of 'politics without conviction' (Palan et al. 2010). Despite a hiatus throughout the early 2000s, the financial crisis of 2008 precipitated renewed attempts to reform the global corporate tax system led by the G20, whose leaders were increasingly advocating reinvigorated efforts to reform the global tax system (Eccleston 2013).

By 2012, the OECD had shifted attention from its previous focus on 
bilateral information exchange agreements to address non-disclosure and offshore tax evasion, to more ambitious multilateral negotiations, in what Palan and Wigan (2014, p.334) refer to as the emergence of 'a genuine consensus for the need for intensive multilateral efforts to tackle tax abuse'. The aim of this reform initiative (OECD 2014b, p.34) was to promote multilateral agreements as a way to enable jurisdictions to develop an 'instrument designed to provide an innovative approach to international tax matters'. The adoption and promotion of automatic exchange of information by the OECD and other actors represent real progress. However, these reforms are only a single battle in a wider war, and do little to address the larger and more complex problems of international tax avoidance and competition which are the focus of this study.

Fundamental reform of the international tax regime may have been too politically contentious to warrant serious consideration in the early 2000 s, but in the aftermath of the financial crisis the political economy of international taxation has changed, and more ambitious and fundamental reform is on the political agenda. The most significant of these developments is the OECD's BEPS initiative, which, as the name suggests, has the broader ambition of limiting the lawful tax avoidance and planning widely practised by MNCs. The BEPS initiative is discussed in greater detail in Chapter 2, where it is argued that its effectiveness requires unprecedented levels of international cooperation. BEPS enjoys significant and unprecedented political support both in the public arena and among the G20 leaders. However, its success hinges on member states' continued cooperation and an unwavering commitment to implementation and compliance amid growing resistance from some governments and large corporations.

While multilateral approaches to combating tax avoidance remain central to the OECD's efforts, they have not been embraced unequivocally by national governments. In the face of the slow pace of international political progress at the multilateral level, two of the world's largest economies, the United States and the European Union, have implemented unilateral regulations in order to combat tax avoidance. Although participation by the US and EU at the level of multilateral reform gives the impression of a reinvigorated effort at reining in tax evasion and avoidance, as Palan and Wigan (2014) argue, many of their reform efforts have been decidedly unilateral. This shift is embodied in the United States' Foreign Account Tax Compliance Act (FATCA) and related initiatives known as 'son of FATCA' agreements, which leverage the large markets of the US and EU to demand information exchange from smaller states. FATCA has ushered in a new 'not in my backyard' attitude to tax avoidance, with similar unilateral regulations introduced in other jurisdictions. These unilateral regulations also have significant extraterritorial reach, 'by deploying financial firms as 
tax intermediaries under the threat of withdrawal of market access' (Palan and Wigan 2014, p. 339). Evidence suggests that, while internationalisation may improve the ability of powerful states to increase taxation revenues, FATCA's unilateral nature, and its inherent rejection of multilateral efforts such as those made by the OECD, 'undermines the accountability and legitimacy of the regime' (Eccleston and Gray 2014).

These unilateral approaches, undertaken by powerful states, have reaffirmed arguments about the unfairness of the global tax regimes. Taken together, this perceived unfairness and the slow-moving nature of global tax reform have frustrated those pushing for more fundamental change, particularly tax justice NGOs.

\section{The Rise of Tax Justice NGOs}

Several vocal tax justice NGOs have played a central role in highlighting the issue of MNC tax avoidance. These organisations are particularly concerned with the fairness and equity implications of multinational tax avoidance, arguing that actions by firms to reduce their tax burdens come at the expense of individual citizens, whose social welfare is impacted and who are expected to make up for this reduction in government revenues through increased personal taxation. Much of this advocacy work has taken the form of demanding large firms pay a 'fair share' of taxation. However, while tax justice NGOs have played a significant role promoting global tax reform and highlighting the deficiencies with the current regime, their rise has been relatively recent, especially in comparison to environmental and social justice NGOs.

The first wave of tax justice advocacy groups emerged in the late 1970s when financial deregulation in the world's industrialised economies had led to rapid growth in the offshore finance industry. The first of these was arguably the US-based Citizens for Tax Justice, which was formed in 1979 with the goal of empowering US citizens to fight the country's powerful corporate tax lobby (Citizens for Tax Justice 2015). INGO Oxfam, whose focus more broadly includes campaigning for development and eliminating poverty, also began work on the impact of tax havens on development in the late 1970s (Seabrooke and Wigan 2013). At that time, however, the organisation deemed the issue of tax avoidance too complex to navigate, and it took until 2000 for the issue to reappear on Oxfam's agenda through the publication of the landmark report Tax Havens: Releasing the Hidden Billions for Poverty Eradication (Oxfam 2000). These early attempts at raising awareness of tax avoidance and communicating the implications for various groups indicate the complexity of governing multinational tax avoidance. Oxfam's efforts were aimed at the international or global level, 
while Citizens for Tax Justice were very much focused on domestic US policy - yet neither group was able to capture the attention of policymakers or the public. The abandonment of the issue by Oxfam, despite its obviously detrimental impacts, suggests a complex policy field through which NGOs and other actors struggle to effect change. It is only over the past 15 years, and especially since the financial crisis, that tax justice campaigners have re-emerged as vocal actors in the global tax avoidance debate.

Following the re-emergence of tax justice NGOs in the 2000s, three main players dominate the policy arena. These are TJN, Christian Aid and Oxfam. Each of these NGOs operates internationally. However, not all are equally resourced or structured, and they do not all have an exclusive monopoly on tax justice. For example, as will be explained in Chapter 4, TJN is wholly devoted to addressing issues of tax avoidance, tax competition and tax havens, whereas taxation forms just one area in which Oxfam and Christian Aid campaign. Of the latter, Oxfam is a much larger organisation (total 2013-2014 income £974.1 million) when compared to Christian Aid (total 2013-2014 income £103.6 million) or TJN (total 2013 income £734559). There are significant differences in strategy that result from these organisations' structures. For example, TJN is a small expert network that leverages its connections to larger social justice NGOs. As examined in Chapter 4, the structure of TJN allows it to engage in 'identity switching', that is, moving between professional network domains to push for change in the realm of international corporate taxation. The members at the centre of TJN have expertise in the technical realms of accounting, law and economics. Yet, as Seabrooke and Wigan (2015; this volume, Chapter 4) argue, they have successfully switched identities and leveraged different network domains in order to build alliances and coalitions to reach a wider audience than would otherwise be possible with a limited technical discourse.

TJN was launched in 2003 as a network of activists, academics, lawyers and others working to draw attention to harmful tax practices. TJN's operating model works by highlighting instances of tax avoidance, drawing media attention to these issues and then allowing other organisations or activists to take over the issue (TJN 2015a). This 'agenda-setting' operating model varies greatly from that of Oxfam or Christian Aid, whose work is more focused on delivering analysis and lobbying governments to deliver solutions to the challenges of MNC tax avoidance. TJN has influenced many elements of the international tax reform agenda, including campaigning for automatic information exchange to address international tax evasion, as well as more fundamental reforms designed to address corporate tax evasion, including promoting country-by-country reporting and developing the Global Alliance for Tax Justice and the Fair 
Tax Mark, both of which now exist separately from the TJN in line with the operating model outlined above (TJN 2015a). Above all else, the TJN has prosecuted an effective media engagement strategy to ensure that tax justice remains on the political agenda in many advanced democracies. Oxfam International's goals are much broader and include poverty reduction and development, with the group's tax justice programme falling into the latter category. The organisation's landmark 2000 report was one of the initial drivers of the tax justice movement, and Oxfam remains centrally involved in tax justice advocacy globally. Similarly, Christian Aid is a UK-based organisation focused on development and eliminating poverty and injustice. Its tax justice programme seeks to address the unfairness of MNC tax avoidance through the promotion of three key aims: country-bycountry reporting, automatic information exchange and public registers of beneficial ownership.

In addition to these three key civil society actors other groups such as ActionAid (a Johannesburg-based INGO), Attac and UK Uncut (a grassroots protest movement focused on the UK government's austerity measures) have emerged. Additionally, coalitions such as the Global Alliance for Tax Justice (which includes ActionAid, Christian Aid and Oxfam) bring these INGOs and NGOs together to lobby for effective tax policy and to lead campaigns against tax havens or particular corporations.

While somewhat belated, the emergence of tax justice NGOs highlights civil society's potential power in this policy arena. As noted above, these groups have been successful in agenda setting or bringing the issue of multinational tax avoidance to the attention of publics and policymakers. They have done so through efforts to highlight the inconsistent and unfair nature of corporate tax avoidance in the face of mounting budget challenges and declining public spending in many economies.

\section{The Emergence of New Forms of Tax Governance}

The rise of tax justice NGOs and broader public debate about MNC tax avoidance have had a number of implications. Part of the agenda has been to promote more robust international agreements and to ensure that national governments implement their commitments. However, the growing profile and politicisation of the tax justice debate has also had a direct impact on firms themselves. As this study will highlight, business has begun to develop and participate in new systems of governance in the field of corporate taxation. These include voluntary initiatives reflecting the actions of individual firms as well as multi-stakeholder initiatives involving the NGOs highlighted above. Private governance has long existed in areas such as environmental management, occupational health 
and safety and human rights, where various combinations of business and civil society organisations have taken the lead in self-regulating operations to protect reputations, reassure customers and investors and avert more formal regulation. Yet firms have thus far been reluctant to participate in governance regimes pertaining to corporate taxation, and where these have emerged progress has been slow. The two key private governance regimes in this policy field include voluntary commitments to enhanced transparency in financial reporting and the development of a privately led standard, known as the Fair Tax Mark (this volume, Chapter 10). While the emergence of these governance regimes suggests 'buy-in' on the part of corporations, as Chapter 5 of this volume highlights, voluntary adoption of these initiatives has been low. While many firms have enhanced the transparency of their financial reporting, this has often been due to existing or imminent government legislation requiring this level of detail.

Private standards have also served to highlight the form and viability of more fundamental reform agendas such as a unitary taxation regime (described in more detail in this volume, Chapter 2). The core principle behind unitary taxation is country-by-country reporting, under which firms provide separate country-level revenue, profit and taxation data in all jurisdictions in which they operate. This regime requires firms to go beyond the two currently used global accounting standards, the Generally Accepted Accounting Principles (GAAP) and the International Financial Reporting Standards (IFRS), which allow multinational firms to report revenue, profit and tax paid at the regional or global level (TJN 2015b). This allows firms to conceal complex tax structures by omitting details of revenue and profits earned compared with tax paid in specific jurisdictions. Tax justice NGOs and many independent experts have campaigned for the introduction of mandatory country-by-country reporting, arguing that forcing firms to report at this level would allow a more complete picture of multinational tax arrangements and is a pre-condition of ensuring that firms pay tax in jurisdictions in which they undertake real economic activity - the so-called 'membership principle' (Dietsch 2015, p.80; this volume, Chapter 2). This campaign has had some early success, most notably in the extractives sector, where enhanced transparency in financial reporting has been seen as a potential solution not only to multinational tax avoidance but also to corruption and human rights violations in developing states (this volume, Chapter 9). In 2013, an update to the EU Transparency and Accounting Directive saw country-by-country reporting mandated for firms in the oil, gas, mining and forestry sectors where payments to governments exceeded $€ 100000$ (European Union 2013). This follows attempts by the US government to implement similar standards. The US Dodd-Frank Wall Street Reform and Consumer Protection Act (Dodd-Frank Act) was 
implemented in 2010 following the global financial crisis and included a provision that all SEC reporting firms involved in the oil, mining and gas industries report detailed financial results at the country level. However, this particular clause of the Dodd-Frank Act was suspended soon after enactment following successful litigation by the American Petroleum Institute (Mehra 2013), and other key provisions of the Dodd-Frank Act were repealed by the Trump administration's Financial Choice Act of June 2017. In both the US and the EU, proposals to enhance reporting requirements have been confined to the extractive sectors, and in the case of the US even on this limited scale efforts have been unsuccessful. We argue that these developments suggest firms are reluctant to embrace new norms around taxation transparency, and that campaigns to enhance transparency in reporting have had limited success to date.

In addition to promoting private standards such as those described above, civil society groups can have other impacts on the international tax regime. For example, they can play an important agenda-setting role as private standards may, over time, be adopted by intergovernmental organisations and implemented in treaties or domestic law. Secondly, as outlined in Chapters 4 and 6, tax justice campaigns may influence the corporate strategies and compliance behaviours of firms and their advisers, thus having a material effect on the international tax regime.

The emergence of tax justice NGOs and associated voluntary governance regimes highlights how multinational tax avoidance is a complex policy arena with competing actors including states, intergovernmental organisations, civil society and firms. Non-state actors are increasingly lobbying governments to act on the challenges of tax avoidance, and NGOs in particular have been successful at garnering popular support for measures such as increased transparency in financial reporting and a more effective international corporate tax regime. However, it has taken considerable time for these NGOs to emerge, and the governance regimes they have developed and promoted remain embryonic. The slow-moving nature of multilateral reform and the hesitance of states to erode their competitive advantage in the pursuit of greater corporate tax revenue have opened space for multi-stakeholder governance initiatives. It is these initiatives, and the civil society actors that promote them, that are the focus of this volume.

\section{THEORETICAL AND EMPIRICAL AIMS}

Why examine the role of new forms of governance in the international tax arena? The answer lies in the fact that despite several false starts the 
civil society campaign against multinational tax avoidance is gaining momentum. The issue of tax avoidance is becoming more salient, yet the barriers to effective governmental and intergovernmental responses highlight the persistent challenges of contemporary global governance. Thus this volume, and its analysis of the role of civil society organisations in combating corporate tax avoidance, is timely while making several theoretical and empirical claims.

Firstly, the collection contributes to debates in the globalisation literature over the drivers and effectiveness of private governance as a solution to otherwise 'ungovernable' problems. In this light, the study provides insights into the supply of and demand for new forms of governance in cases where states have been unwilling, or unable, to implement effective governance regimes. In addition it provides a critical assessment of the changing nature of power and authority in the global economy and examines the prospects of hybrid regulatory regimes more generally. In this vein, the study also addresses questions on the legitimacy and effectiveness of privately led governance and the manner in which this is assessed by governments and other non-state actors such as consumers, firms and NGOs. Lastly, the volume provides a unique contribution to the literature on activism and social movements by providing insights into the manner in which actors with technical expertise leverage connections with wider social movements.

At an empirical level, the book provides one of the first in-depth studies into the scope and potential of new forms of governance emerging in response to the challenges of corporate taxation. A central aim is to evaluate the power and influence of NGOs, and assess civil society's potential to promote international tax reform. The study offers several responses to these questions. Chapter 7 focuses on corporate responses to the push for greater transparency and highlights the continued resistance of firms to calls for greater disclosure, as evidenced by a lack of concern about corporate reputation from some of the largest and most well-known MNCs. The book also interrogates the legal basis for many of these initiatives, and by extension the legitimacy that may or may not be afforded to recent efforts at global tax reform. In particular, contributions by Christians (Chapter 10) and Gale and Murphy-Gregory (Chapter 11) evaluate the legal basis of standards promoted by activists such as TJN and the Fair Tax Mark, as well as the transparency and accountability credentials of the initiatives themselves. The study concludes with a preliminary evaluation of the prospects for global tax justice and the extent to which fiscally challenged governments are going to be able to extract revenues from large corporations.

The study employs several key concepts and terms which require 
elaboration owing to their contested nature. Firstly, the concept of voluntary governance is a central focus of this study. Contained within this is the notion of private governance, that is, regulation implemented by firms with significant private authority which is regarded as legitimate by other actors. It should be noted that this form of governance goes beyond self-regulation. Instead, private governance requires a level of perceived legitimacy that is reflected in the behaviour of other actors, who abide by these rules not out of self-interest but out of 'recognition of the legitimacy of the governance system' (Falkner 2003, p. 73). We argue that private governance is becoming more important in the international tax arena but often in combination with various forms of public authority, resulting in new forms of 'hybrid' governance regimes (Crouch 2004).

In terms of the analytical focus of the study we use the term 'tax avoidance' in preference to the narrower concept of 'tax evasion', which denotes illegal activity. As noted above, this study is specifically concerned with the more contested concept of MNC tax avoidance, that is, the use of complex tax structures that operate within existing legal frameworks but minimise or eliminate a firm's tax obligations. On a related note, the terms 'tax secrecy jurisdiction' and 'tax haven' are used interchangeably throughout this collection. While there is no one agreed definition of a tax haven or secrecy jurisdiction, this volume follows the OECD definition of tax havens as having 'the following key characteristics; no or only nominal taxes; lack of effective exchange of information; lack of transparency in the operation of the legislative, legal or administrative provisions' (OECD 2016). Finally, many will agree that the use of complex transnational regimes and financial structures to minimise tax liabilities constitutes tax avoidance, but this is a subjective measure, and the line between deliberate tax evasion and claiming legitimate business deductions is inherently blurred and contested. While acknowledging these ambiguities in Chapter 2 , we provide an overview of key contributions from the contemporary literature on the ethics of taxation to provide some defensible guidelines as to the features of a 'fair' international tax regime and its implications for reform (Dietsch 2015).

\section{OVERVIEW}

The volume begins with a detailed assessment of the political challenges associated with taxing MNCs. Part I begins with a contextual outline of the origins and the problem of international tax avoidance associated with the rise of MNCs. Detailed consideration is given to the distinction between tax avoidance and tax evasion - a point which highlights the 
contested nature of fairness in the international corporate taxation system. In Chapter 1 Richard Woodward provides a historical overview of early tax campaigns and anti-avoidance measures, followed, in Chapter 2, by Richard Eccleston's analysis of the more recent shift to focusing on the tax avoidance strategies of firms and finally the introduction of BEPS. Chapter 2 concludes by presenting the philosophical and technical case for the unitary taxation of corporate income, which is increasingly the focus of the global tax justice campaign. Part I concludes with Ainsley Elbra's contribution (Chapter 3), outlining emerging forms of tax activism and private governance, including the emergence of tax justice NGOs, media and community engagement, firm-specific campaigns, standard setting and benchmarking, and investor activism.

Part II of this volume examines the strategies of various actors in the arena of private tax governance. As outlined earlier in this Introduction, the governance of corporate taxation involves multiple actors operating at various levels; Part II describes the strategies of these participants. Leonard Seabrooke and Duncan Wigan's contribution (Chapter 4) examines the strategies of tax activists, in particular TJN. This chapter highlights the key campaigns and strategies of these actors, and their links to other NGOs, tax professionals and the media. Aynsley Kellow's contribution (Chapter 5) analyses the legitimacy challenges of civil society organisations in the international tax arena and the associated limits of private governance. He highlights the centrality of norms including 'fairness' in any private governance regime and the manner in which they render the legitimacy of actors such as NGOs critical. Kellow provides an overview of the literature on NGOs and examples of legitimacy deficits, and concludes by examining the scholarship on the legitimacy of transnational activists. Following from this, Lyne Latulippe's chapter on the critical role of tax professionals (Chapter 6) examines the strategies and governing roles of professional tax advisers. She highlights the crucial role of these key intermediaries in the provision of advice as well as the implementation of complex taxation strategies. The chapter goes on to examine the interlinkages between tax professionals and NGOs and the manner in which the former respond to 'fairness' campaigns waged by the latter. Part II concludes with the contribution from John Mikler and Ainsley Elbra (Chapter 7) on corporate responses to tax justice campaigns, in particular through firms' participation in parliamentary inquiries into corporate taxation. This chapter argues there is a continued preoccupation with shareholder value maximisation over corporate reputation, and that a liberal ideological belief in free markets dominates corporate conceptions of their legitimacy in debates about paying their fair share of tax.

Part III of the book focuses on the theoretical underpinnings of private 
and hybrid governance and the application of these regimes in other domains of global governance. Opening Part III, Tony Porter and Karsten Ronit (Chapter 8) examine the scope and forms of private governance, including providing an overview of the theories of private governance and compliance as well as the institutional and political pre-conditions for effective private governance. The chapter concludes by examining the extent to which these pre-conditions exist in the corporate tax arena. Following this, James Van Alstine and Laura Smith (Chapter 9) examine the most established quasi-private taxation regime, the Extractive Industries Transparency Initiative (EITI). This chapter provides an overview of the EITI, including the unusual quasi-private nature of this standard, whereby the regime was developed by firms and INGOs but is implemented by national governments. Van Alstine and Smith also examine the manner in which the EITI encourages enhanced transparency on the part of firms and the future challenges for the initiative. Allison Christians's chapter (Chapter 10) discusses the legal considerations pertinent to voluntary efforts such as the Fair Tax Mark, as well as the impact of high-profile litigation such as the European Commission's 2016 state aid case against Apple. In this chapter, Christians highlights the fact that many forms of private governance do not possess a solid legal dimension. She outlines the enforcement challenges associated with these cases and asks what is the likelihood of disputes and who will adjudicate such conflicts. Next, Fred Gale and Hannah Murphy-Gregory's contribution (Chapter 11) explores lessons from the Forest Stewardship Council (FSC) and Fairtrade campaigns. Gale and Murphy-Gregory suggest that the international tax arena is something of a laggard in terms of private governance, a theme which is central to the wider study. Their contribution examines legitimacy in global private governance, how this has been achieved in the FSC and Fairtrade cases, and what lessons can be learned in the area of taxation private governance. In the final chapter, Lachlan Johnson (Chapter 12) discusses the emerging potential private governance role of whistleblowers, data leakers and investigative journalists. Drawing on survey data and accounting research, Johnson's chapter considers the impacts of reputational damage, issue salience and public awareness raised by massive data leaks - such as the Panama Papers and Paradise Papers - on the cost-benefit calculus of MNC tax planning.

The Conclusion brings the volume to a close with Richard Eccleston and Ainsley Elbra's preliminary assessment of the effectiveness of voluntary governance in the international tax arena. Eccleston and Elbra summarise the preliminary evidence presented in the study pertaining to the collective impact of the emerging governance regimes, including the central question of whether these initiatives have led to altered behaviour 
on the part of firms or whether they have precipitated other regulatory responses. The Conclusion ends by considering the prospects of alternative mechanisms for enhancing the global corporate taxation regime, including investor and financier activism, as well as the broader theme of the significance of private global economic governance in the early twenty-first century.

\section{REFERENCES}

Apeldoorn, L. van (2016), 'International Taxation and the Erosion of Sovereignty', in P. Dietsch and T. Rixen (eds), Global Tax Governance: What Is Wrong with It and How to Fix It, Colchester: ECPR Press, pp. 215-230.

Aston, H. and G. Wilkins (2014), 'ASX 200 Company Tax Avoidance Bleeds Commonwealth Coffers of Billions a Year, Report Finds', Sydney Morning Herald, available at http://www.smh.com.au/business/the-economy/asx-200-com pany-tax-avoidance-bleeds-commonwealth-coffers-of-billions-a-year-report-finds -20140927-10n3n3 (accessed 9 November 2016).

Australian Senate (2015), 'Corporate Tax Avoidance', Australian Senate Economics References Committee.

Bell, S. (2012), 'The Power of Ideas: The Ideational Shaping of the Structural Power of Business', International Studies Quarterly 56 (4), 661-673, doi:10.1111/j.1468-2478.2012.00743.x.

Christians, A. (2013), 'How Starbucks Lost Its Social License - And Paid $£ 20$ Million to Get It Back', Tax Notes International 71 (7), available at SSRN: https://ssrn.com/abstract $=2308921$ (accessed 6 November 2016).

Christians, A. (2015), 'Friends with Tax Benefits: Apple's Cautionary Tale', Tax Notes International 78 (11), available at SSRN: https://ssrn.com/abstract $=2674335$ (accessed 12 November 2016).

Citizens for Tax Justice (2015), 'Background and History', available at http://ctj. org/about/background.php (accessed 11 November 2016).

Clausing, K. (2016), 'The Nature and Practice of Tax Competition', in P. Dietsch and T. Rixen (eds), Global Tax Governance: What Is Wrong with It and How to Fix It, Colchester: ECPR Press, pp. 27-54.

Crouch, C. (2004), 'Hybrid Governance and Networked Firms', in C. Crouch, P. Le Galès, C. Trigilia and H. Voelzkow, The Changing Governance of Local Economies, Oxford: Oxford University Press, pp. 119-128.

Dietsch, P. (2015), Catching Capital: The Ethics of Tax Competition, New York: Oxford University Press.

Dietsch, Peter and Thomas Rixen (eds) (2016), Global Tax Governance: What Is Wrong with It and How to Fix It, Colchester: ECPR Press.

Eccleston, R. (2013), The Dynamics of Global Economic Governance: The Financial Crisis, the OECD and the Politics of International Tax Competition, Cheltenham, UK and Northampton, MA, USA: Edward Elgar Publishing.

Eccleston, R. and F. Gray (2014), 'Foreign Accounts Tax Compliance Act and American Leadership in the Campaign against International Tax Evasion: Revolution or False Dawn?', Global Policy 5 (3), 321-333, doi:10.1111/1758-5899. 12122. 
Eccleston, R. and H. Smith (2016), 'The G20, BEPS and the Future of International Tax Governance', in P. Dietsch and T. Rixen (eds), Global Tax Governance: What Is Wrong with It and How to Fix It, Colchester: ECPR Press, pp. 175-198.

European Union (2013), Directive 2013/34/EU of the European Parliament and of the Council on the annual financial statements, consolidated financial statements and related reports of certain types of undertakings, amending Directive 2006/43/ EC of the European Parliament and of the Council and repealing Council Directives 78/660/EEC and 83/349/EEC, available at http://eur-lex.europa.eu/ LexUriServ/LexUriServ.do?uri=OJ:L:2013:182:0019:0076:EN:PDF (accessed 11 November 2016).

Falkner, R. (2003), 'Private Environmental Governance and International Relations: Exploring the Links', Global Environmental Politics 3 (2), 72-87, doi: $10.1162 / 152638003322068227$.

Genschel, P. and P. Schwarz (2011), 'Tax Competition: A Literature Review', Socio-economic Review 9 (2), 339-370.

Gravelle, J.G. (2015), Tax Havens: International Tax Avoidance and Evasion, Vol. R40623, Washington, DC: Congressional Research Service.

Henry, J. (2016), 'Let's Tax Anonymous Wealth!', in T. Pogge and K. Mehta (eds), Global Tax Fairness, Oxford: Oxford University Press, pp. 31-95.

Kavoussi, B. (2012), 'Google Chairman Eric Schmidt Defends Tax Dodge: "It's Called Capitalism"', Huffington Post, available at http://www.huffingtonpost. com.au/entry/google-tax-dodge_n_2292077.html?section=australia (accessed 1 November 2016).

Lindblom, C.E. (1977), Politics and Markets: The World's Political Economic Systems, New York: Basic Books.

Mehra, A. (2013), 'Oil Companies Are on a Slippery Slope with Their First Amendment Claim against Disclosure Rules', Forbes.com, available at http:// www.forbes.com/sites/csr/2013/02/28/5802/ (accessed 4 November 2016).

OECD (1998), Harmful Tax Competition: An Emerging Global Issue, Paris: OECD Publishing.

OECD (2014a), 'Government Debt', Economics: Key Tables from OECD, No. 21, available at http://dx.doi.org/10.1787/gov-debt-table-2014-1-en (accessed 21 December 2017).

OECD (2014b), OECD/G20 Base Erosion and Profit Shifting Project: Developing a Multilateral Instrument to Modify Bilateral Tax Treaties, Paris: OECD Publishing.

OECD (2015), 'Reforms to the International Tax System for Curbing Avoidance by Multinational Enterprises', available at http://www.oecd.org/tax/g20finance-ministers-endorse-reforms-to-the-international-tax-system-for-curbingavoidance-by-multinational-enterprises.htm (accessed 1 November 2016).

OECD (2016), 'Glossary of Tax Terms', available at http://www.oecd.org/ctp/ glossaryoftaxterms.htm\#T (accessed 10 November 2016).

Oxfam (2000), Tax Havens: Releasing the Hidden Billions for Poverty Eradication, available at http://www.taxjustice.net/cms/upload/pdf/oxfam_paper_-_final_ver sion_06_00.pdf (accessed 1 November 2016).

Palan, R. (2002), 'Tax Havens and the Commercialization of State Sovereignty', International Organization 56 (1), 151-176, doi:10.1162/002081802753485160.

Palan, R. and D. Wigan (2014), 'Herding Cats and Taming Tax Havens: The US Strategy of "Not in My Backyard"', Global Policy 5 (3), 334-343, doi:10.1111/ 1758-5899.12135. 
Palan, R., R. Murphy and C. Chavagneux (2010), Tax Havens: How Globalization Really Works, Ithaca, NY: Cornell University Press.

Picciotto, S. (2016), 'Towards Unitary Taxation: Combined Reporting and Formulary Apportionment', in T. Pogge and K. Mehta (eds), Global Tax Fairness, Oxford: Oxford University Press, pp. 221-237.

Rixen, T. (2008), The Political Economy of International Tax Governance: Transformations of the State, New York: Palgrave Macmillan.

Rixen, T. (2011), 'Tax Competition and Inequality: The Case for Global Tax Governance', Global Governance 17, 447-467.

Seabrooke, L. and D. Wigan (2013), Emergent Entrepreneurs in Transnational Advocacy Networks: Professional Mobilization in the Fight for Global Tax Justice, Working Paper No. 41, GR:EEN, Global Reordering: Evolution through European Networks, FP7, available at http://pipesproject.eu/assets/GREEN41. pdf (accessed 1 November 2017).

Seabrooke, L. and D. Wigan (2015), 'How Activists Use Benchmarks: Reformist and Revolutionary Benchmarks for Global Economic Justice', Review of International Studies 41 (5), 887-904.

TJN (Tax Justice Network) (2015a), 'About Us - Our Goals', available at http:// www.taxjustice.net/about/who-we-are/goals/ (accessed 9 November 2016).

TJN (Tax Justice Network) (2015b), 'Country by Country Reporting', available at http://www.taxjustice.net/topics/corporate-tax/country-by-country/ (accessed 9 November 2016).

UNCTAD (2015), World Investment Report 2015: Reforming International Investment Governance, Geneva: United Nations.

Weckler, A. (2016), 'Apple and Ireland against the World', Sunday Independent, available at https://www.independent.ie/business/irish/apple-and-ireland-againstthe-world-35018709.html (accessed 12 November 2016). 